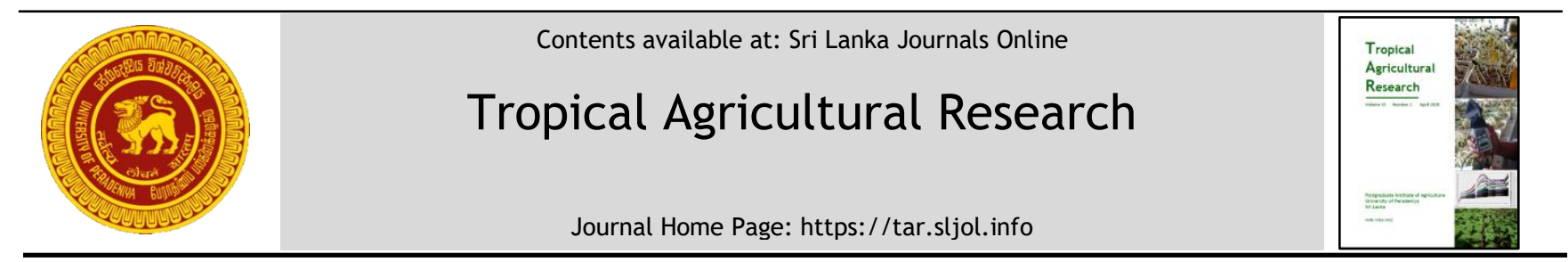

\title{
Changes in Population Densities of Two White-Eye Species (Passeriformes: Zosteropidae) Along an Altitudinal Gradient in Sri
}

\section{Lanka}

\author{
C.S. Wijesundara ${ }^{1 *}$, S.K. Yatigammana ${ }^{2}$ and P. Silva ${ }^{1,3}$ \\ ${ }_{1}^{1}$ Postgraduate Institute of Agriculture, University of Peradeniya, Peradeniya, Sri Lanka \\ ${ }^{2}$ Department of Zoology, Faculty of Science, University of Peradeniya, Peradeniya, Sri Lanka \\ ${ }^{3}$ Department of Animal Science, Faculty of Agriculture, University of Peradeniya, Peradeniya, Sri Lanka
}

\section{ARTICLE INFO}

\section{Article history:}

Received: 15 August 2019

Accepted: 02 November 2019

Available online: 1 April 2020

\section{Keywords:}

Altitudinal gradient

Allopatry

Density

Species replacement

Sympatry

\section{Citation:}

Wijesundara, C.S., Yatigammana, S.K. and Silva, P. (2020). Changes in Population Densities of Two White-Eye Species (Passeriformes: Zosteropidae) Along an Altitudinal Gradient in Sri Lanka. Tropical Agricultural Research, 31(2): 29-40.

DOI: http://doi.org/10.4038/tar.v31i2.8365

Chaminda Wijesundara. https://orcid.org/0000-0002-1539-2161

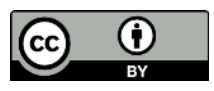

\begin{abstract}
Understanding relationships between population density and habitat quality are crucial in bird conservation attempts. The present study was conducted to document the densities of Sri Lanka White-Eye (Zosterops ceylonensis) (SLWE) and Oriental White-Eye (Z. palpebrosus) (OWE) in solitary and co-existence situations. Censuses of the two white-eye species were conducted in their allopatric and sympatric zones, between September 2017 and June 2019. The allopatric ranges of both species acted as 'controls' for this experiment. Analysis of covariance was used to capture the changes in densities in zones of allopatry whereas, correlation test was done to analyze density changes in sympatric zone. Results showed that there was a marked decline in density of OWE from the end of its allopatric zone to the beginning of sympatric zone. SLWE showed no such change. One-way ANOVA showed that the changes in densities with elevation were significant $(\mathrm{P}<0.01)$, which was supported by the analysis of covariance $(\mathrm{P}<0.01)$. A significant negative correlation $(\mathrm{P}<0.01)$ of density in sympatry with increasing elevation was observed for OWE while SLWE showed no significant correlation between density and elevation, and no negative correlation of densities in sympatry. Association of density of OWE with changes in habitat with elevation was suggested as one possibility since forest structure alone does not limit the distribution of OWE according to its pattern on distribution in India where OWE is the sole white-eye species. Previous studies have also shown that at least one of these species show some character displacement in the sympatric zone. Thus, it can be inferred that SLWE has evolved with sufficient differences for ecological isolation from OWE. This has resulted in ecological release to certain extent where OWE must have been replaced with changes in vegetation structure together with competition from its congeneric species.
\end{abstract}

*Corresponding author : chaminda@hawaii.edu 


\section{INTRODUCTION}

The occurrence of a given species at a given habitat depends on specific environmental conditions (Lisboa and Freire, 2012). Therefore, comparing densities among habitats are essential in understanding ecological patterns and processes. Applied research directed at bird conservation regularly attempts to understand habitat preferences, and the relationships between population density and habitat quality or area (Sutherland et al., 2004). Some authors have traced sharp discontinuities in distributions of bird species with respect to habitat structure by using presence/absence data alone (MacNally, 1990) confirming that this approach appears to be sensitive to sampling of habitat types.

Competition theory predicts that populations of a species that occur in areas or habitats lacking one or more competing species, that exploit some of the same resources, should exhibit ecological release relative to populations occupying similar situations where the competing species are present (MacArthur et al., 1972; Wright, 1980; Pianka, 1981; Wiens, 1989). Population densities may thus be high in the absence of competitors (Wiens, 1989) leading to density compensation (MacArthur et al., 1972; Wright, 1980) where niche breadth of the population can increase with habitat, elevation, foraging or diet. Morphology of these populations may shift in the direction of the missing species, through character displacement (Grant, 1972).

Density compensation can also occur in some guilds within a community (Wiens, 1989). Cody (1983) found that numbers of South African afromontane forest bird species declined along a gradient of increasingly smaller and more isolated habitat-islands where. vegetation structure varied considerably across the gradient. For the Cape white-eye (Zosterops pallidus), density decreased from 2.5 pairs/ha where it occurred alone and with a single additional species, down to one third of this level where it coexisted with four additional species (Grant, 1972).
A strong correlation between the total vegetation volume and breeding bird density has been recorded previously for some bird communities in Arizona and New Mexico in the United States (Mills et al., 1991). Swift et al. (1984) showed that significant variation in total breeding bird density and abundance in some feeding guilds could be explained by habitat variables. Another study by Andrén (1992) showed that, in Sweden, the density of corvids increased as forest became fragmented and intermixed with agricultural land. Similarly, a number of other studies have shown correlations of bird density and diversity with vegetation (Hooper et al., 1973; Cody, 1981; James and Wamer, 1982; Kutt, 1996; Kinley and Newhouse, 1997; Moreira, 1999; Fondell and Ball, 2004; Winter et al., 2005; Fischer et al., 2012).

In the present study, two closely related white-eye species found in Sri Lanka were used as a model system to investigate species replacement through local adaptation as a result of competition. The two species were Sri Lanka White-Eye (SLWE); Zosterops ceylonensis, which is endemic to Sri Lanka, and Oriental White-Eye (OWE); $Z$. palpebrosus, which is a native species in Sri Lanka, also found in other countries. The former is slightly larger in size, has a stronger bill, and darker olive and lesser yellow back side (Ali and Ripley, 2001). The SLWE inhabits exclusively the high elevations.

SLWE is usually found in pairs during the breeding season. Outside the breeding season, it may be found in large scattered flocks (Ali and Ripley, 2001). It appears to be more sociable than the OWE which is found in forests, groves, gardens, orchards, and also in mangroves (Ali and Ripley, 2001). OWE usually goes in pairs or small flocks, frequently in company with small babblers or other insectivorous bird species (Henry, 1971; Ali and Ripley, 2001). It is an entirely arboreal species, only descending to ground level to bathe.

According to the preliminary studies it was observed that there is a marked decline in the density of OWE from the end of its allopatric zone to the beginning of the sympatric zone, whereas the SLWE does not show such a 
change between allopatric and sympatric zones. The density of the OWE decreased from the lower end of the zone of sympatry to the upper end of the zone of sympatry indicating that there is gradual replacement of the OWE in the upper elevations. This gradual replacement may partly be due to certain morphological differences (Wijesundara and Freed, 2018). Thus, the objective of the present study was to assess the variations of densities of the two whiteeye species where they co-exist and exist separately.

\section{MATERIALS AND METHODS}

Censuses of the two white-eye species were conducted in areas of allopatry and sympatry of the species, between September 2017 and June 2019 (Table 1). Censuses were conducted between sunrise and sunset of each census day, with peak counting hours between $0630 \mathrm{~h}$ and $1000 \mathrm{~h}$ and $1530 \mathrm{~h}$ and $1830 \mathrm{~h}$. The peak counting hours represented the time period of the day when birds were most active (Mulwa et al., 2007). All field observations were carried out by the first author.

Birds were counted using a line transect integrated point count method along lines located using a systematic random procedure according to the Distance Sampling Protocol (Buckland et al., 1993; Buckland et al., 2001; Thomas et al., 2002; Thomas et al., 2010a). When using line transects integrated with point counts, some important features of Distance Sampling are that radial distance should be measured from the observer to the animal's original location, movement of animals after detection is not a problem as long as the original location can be established accurately and the appropriate distance was measured. It is of concern if an animal is detected more than once along the same transect, and the program fully allows for the fact that many animals not on the point count station will remain undetected (Buckland et al., 1993; Buckland et al., 2001).

Birds were censured in a total of 47 point transects covering all habitats in the zones of allopatry and sympatry of both species (Figure 1), with at least two replicates per elevation. The number and length of transects were determined by the total area of the habitat available. Whenever possible, existing trails were uased to avoid cutting of vegetation. When using point counts, this layout was permissible (Buckland et al., 1993, Buckland et al., 2001).

Table 1: Sampling areas in the allopatric and sympatric areas of the two white-eye species for density estimation (OWE=Oriental White-Eye; SLWE=Sri Lanka White-Eye; NP=National Park; SNR=Strict Natural Reserve; VRR=VictoriaRandenigala-Rantambe).

\begin{tabular}{lc}
\hline \multicolumn{1}{c}{ Area } & Species \\
\hline Hantana & OWE allopatric \\
Dekinda & OWE allopatric \\
Alagalla & OWE allopatric \\
Naranga & OWE allopatric \\
Kaluwagala & OWE allopatric \\
VRR Sanctuary & OWE allopatric \\
Ramboda & OWE allopatric \\
Bambarakele & OWE/SLWE \\
& sympatric \\
Bomuralla & OWE/SLWE \\
& sympatric \\
Galway's Land NP & OWE/SLWE \\
& sympatric \\
Hakgala SNR & OWE/SLWE \\
Ambewela & sympatric \\
Pattipola & OWE/SLWE \\
Horton Plains NP & Sympatric \\
\hline
\end{tabular}




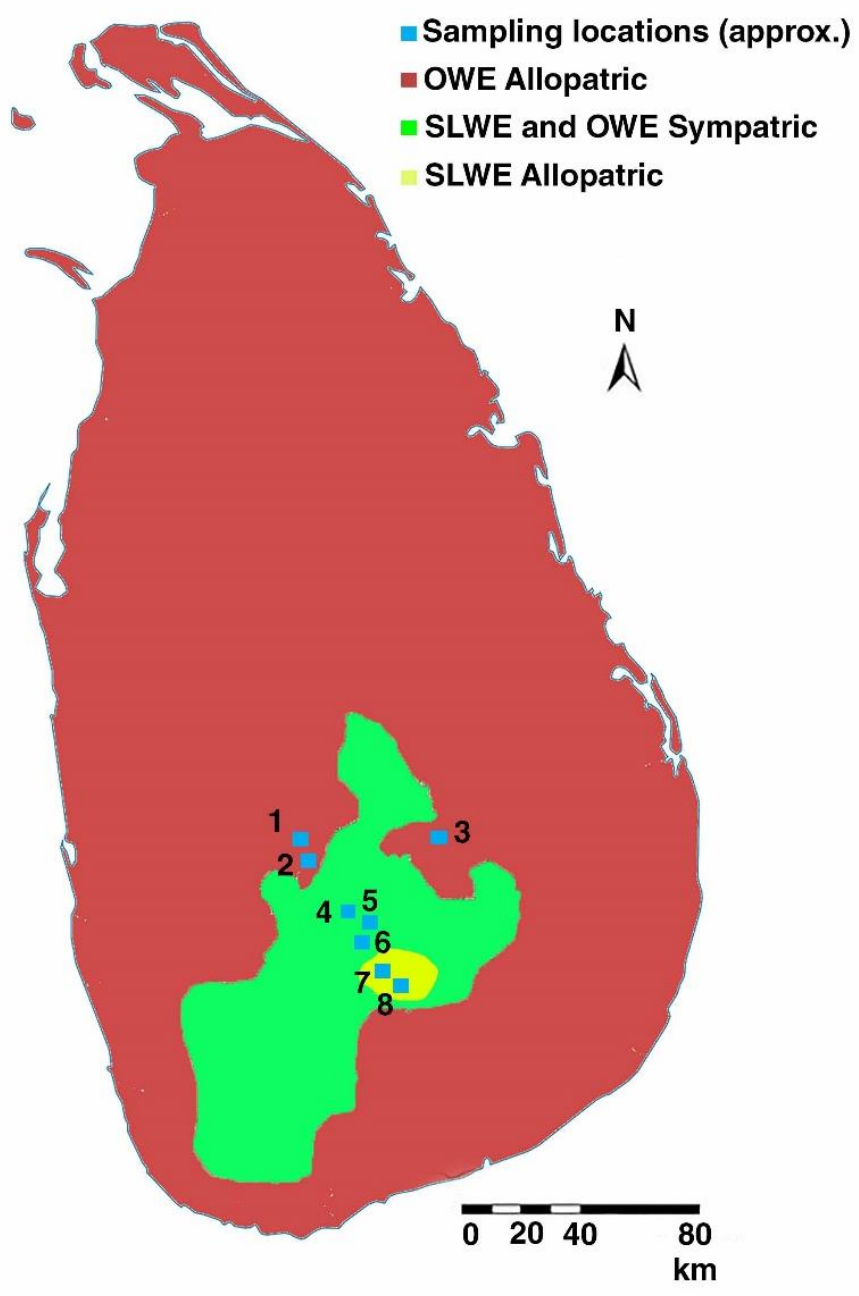

Figure 1: Distribution of Sri Lanka white-eye (SLWE) and Oriental white-eye (OWE). Sampling locations in the present study are shown as blue squares each of which had six sampling sites except location 4, which had only five (Modified from Wijesundara and Freed, 2018).

The allopatric ranges of both species considered as controls for the study. About 10-15 minutes were spent at each point count station. Once an individual or a group of individuals (flock) was seen or heard, the original locations were noted down and the distance was estimated using a range-finder (Bushnell Yardage Pro Compact 800, Bushnell Corporation, Kansas, U.S.A.), and the number of individuals (in the case of flocks) were counted. For observing birds and counting individuals in each flock, $8 \times 40$ and $10 \times 42$ standard birding binoculars (Nikon $8 \times 40$ Action Extreme; Nikon Monarch $10 \times 42$ ) were used. In places where dense canopy made it impossible to count individuals because of low visibility, counting was done when the birds moved from one tree to another, following the method employed by
Mulwa et al. (2007). To minimize time-of-day bias, each point count station was given an equal chance of visitation during different times of day. By dividing the day into different census sessions (e.g. 0630-1000 h and $1530-1800 \mathrm{~h}$ ), it was possible to spend approximately equal amount of sampling in each session during the study period. On each visit, the radial distance to the individual or flock from the point count station was estimated and the flock size was noted. DISTANCE version 6.2 (Thomas et al., 2010b) was used to analyse the data.

Analysis of covariance was done to analyse the changes in densities in the zones of allopatry. The model included density from beginning of zone with species as a factor. Correlation test was carried out to analyze 
the changes in densities in the zone of sympatry. Results were considered significant at $\alpha=0.05$. Both tests were carried out using Minitab 16 statistical software (Minitab, Inc., 2010).

\section{RESULTS AND DISCUSSION}

Comparing densities is important given the size of the zone of sympatry, which is greater than those described in most previous studies of species replacement (Haffe,r 1969; Terborgh, 1971; Diamond, 1973; Haffer, 1974; Terborgh, 1977; Mallet-Rodrigues et al., 2010). Table 2 shows the densities of the two white-eye species in the study areas in sympatric and allopatric zones. Changes of density of two species of white-eyes along an altitudinal gradient (Figure 2) showed that there was a marked decline in the density of the OWE from the end of its allopatric zone to the beginning of its sympatric zone, and in general, it showed a trend of decreasing density with increasing altitude. The SLWE showed no such change from its sympatric to allopatric zones. The highest density of OWE was recorded at an elevation of $550 \mathrm{~m}$ a.s.l., and the lowest at Ambewela (1842 m a.s.l.). This species was not found beyond that elevation. Density of SLWE also showed a slight decreasing trend but was not as sharp as that of the OWE. In general, the density of the SLWE was more or less the same throughout its range, from $1745 \mathrm{~m}$ to $2165 \mathrm{~m}$. Within the zone of sympatry, the OWE showed a decreasing trend in its density from the edge of its allopatric range to the edge of the allopatric range of the SLWE.

Both one-way ANOVA and analysis of covariance confirmed that densities of SLWE changed significantly $(\mathrm{P}<0.01)$ with elevation. According to the Pearson correlation test for sympatric area there was a significant negative correlation of density with increasing elevation for the OWE $(\mathrm{P}<0.01)$ while SLWE showed no significant correlation.

Even though it was expected that there could be a negative correlation of densities in the overlapping range, it was not shown by
SLWE, suggesting that only OWE density is associated with habitat in the zone of sympatry. During the present study, it was observed that the habitat changed with elevation. The nature of tree species changed with elevation, from the beginning to the end of the zone of sympatry. In general, the trees became shorter in height from the edge of its allopatric range to the edge of the allopatric range of the SLWE. At the highest elevations, the forest becomes a 'pygmy forest', and this is where the SLWE was observed in allopatry. In this zone, it was noted that the structure of the trees was different where trees were often gnarled, with rough bark, and they rarely exceeded $20 \mathrm{~m}$ in height. This has also been observed previously by Perera (1975).

In India, where only the OWE is found, the vegetation structure changes with elevation (Blasco et al., 1996; Ali and Ripley, 2001). However, OWE in India is found from the sea level up to the summits of high mountains. Therefore, the forest structure alone does not seem to limit the distribution of OWE. In Sri Lanka, the gradual replacement of OWE by SLWE starts approximately at an elevation of $1700 \mathrm{~m}$ a.s.l., and the former species is completely replaced by the latter species at an elevation of about $1900 \mathrm{~m}$ a.s.l. The vegetation type in this zone is montane rainforests. Thus, the vegetation structure alone is not the cause of this replacement. In fact, in the present study, it was found that SLWE did not change its density significantly from the allopatric to the sympatric zones. However, the SLWE was found in its maximum density in the sympatric zone (Bomuralla site, 24.2 birds/ha). This has previously been reported for birds in New Guinea (Diamond, 1973) where two species of warblers, Crateroscelis murina and $C$. robusta, which differ ecologically in their altitudinal range, replaced each other at a certain elevation in which they had their maximum abundance. Accordingly, with increasing elevation $C$. murina became increasingly abundant, and at $1643 \mathrm{~m}$, which is not far from its altitude of maximum abundance, it suddenly disappeared while $C$. robusta suddenly appeared near its maximum abundance. 
Table 2: White-eye densities (birds per ha) in surveyed areas in sympatry and allopatry. [OWE=0riental White-Eye; SLWE=Sri Lanka White-Eye; ALLO=Allopatric; SYM=Sympatric; NP=National Park; SNR=Strict Natural Reserve; VRR=VictoriaRandenigala-Rantambe]

\begin{tabular}{|c|c|c|c|}
\hline Species-Allopatic/Sympatric-Area & $\begin{array}{l}\text { Elevation } \\
\text { (m a.s.l.) }\end{array}$ & $\begin{array}{l}\text { Density } \\
\text { Estimate of } \\
\text { OWE }( \pm \text { SE })\end{array}$ & $\begin{array}{l}\text { Density } \\
\text { Estimate of } \\
\text { SLWE }( \pm \text { SE) }\end{array}$ \\
\hline OWE-Allo-Hantana & 540 & $14.61 \pm 3.88$ & \\
\hline OWE-Allo-Dekinda & 490 & $15.67 \pm 3.03$ & \\
\hline OWE-Allo-Alagalla & 609 & $17.31 \pm 8.01$ & \\
\hline OWE-Allo-Naranga & 544 & $22.05 \pm 12.2$ & \\
\hline OWE-Allo-Kaluwagala & 559 & $18.06 \pm 7.38$ & \\
\hline OWE-Allo-VRR Sanctuary & 201 & $16.32 \pm 5.89$ & \\
\hline OWE-Allo-Ramboda & 964 & $14.16 \pm 7.49$ & \\
\hline OWE-SLWE Sym-Bambarakele & 1910 & $2.74 \pm 2.10$ & $23.93 \pm 11.69$ \\
\hline OWE-SLWE Sym-Bomuralla & 1805 & $4.91 \pm 4.02$ & $24.22 \pm 5.48$ \\
\hline OWE-SLWE Sym-Galway's Land NP & 1935 & $1.62 \pm 1.48$ & $19.55 \pm 8.26$ \\
\hline OWE-SLWE Sym-Hakgala SNR & 1891 & $2.59 \pm 1.43$ & $18.73 \pm 7.24$ \\
\hline OWE-SLWE Sym-Ambewela & 1846 & $1.44 \pm 1.11$ & $20.73 \pm 15.06$ \\
\hline SLWE-Allo-Pattipola & 1972 & & $22.57 \pm 22.91$ \\
\hline SLWE-Allo-Horton Plains NP & 2111 & & $20.66 \pm 18.87$ \\
\hline
\end{tabular}

In the present study, the OWE showed its maximum density in its allopatric zone, while its density was drastically reduced (from 14.16 birds/ha to 2.58 birds/ha) in the sympatric zone (Figure 2). In general, the vegetation structure did not change drastically in this area, but there was a marked decline in the OWE in the presence of the SLWE. Furthermore, the average density for this species in the allopatric zone was 16.87 birds/ha whereas the average density in the sympatric zone was 2.66 birds/ha. The SLWE did not show a significant change in its average density in allopatric and sympatric zones (i.e. 21.61 and 21.43 birds/ha respectively). A previous study has shown that the density of the Cape White-Eye (Zosterops pallidus) decreased from 2.5 pairs/ha where it occurred alone and with a single additional species, down to one third this level where it coexisted with four additional species (Cody 1983). This trend of declining density in higher-diversity systems was not shown by any of the other species in Cody's study system. The summed density of the two white-eye species was more or less constant in the sympatric zone (Figure 2). This observation is consistent with observations of Cody (1983) for South African Afromontane forest birds.

It has previously been reported that SLWE had some of its morphological measurements diverged in the sympatric zone (Wijesundara and Freed, 2018). As shown in their study, SLWE in the sympatric zone had a significantly different bill length and width from those in the allopatric zone, suggesting that SLWE has evolved sufficient differences to be ecologically isolated from its congeneric species, the OWE. This has resulted in ecological release (lack of competition) to a certain extent. Together with changes in vegetation structure and the competition 
from its congeneric species, the OWE must have been replaced.

Competition is evident in the changes of some morphological characters, especially those related feeding. The OWE is generally observed at high foraging levels (heights) in its allopatric range. The SLWE is observed to be equally at home both at high and low foraging levels. These observations are consistent with the observations of previous workers (Legge, 1880; Wait, 1922; Wait, 1925; Henry, 1971; Henry, 1998; Ali and Ripley, 2001). The shortening of vegetation structure explains part of the reason for lowered densities of the OWE starting from the lower end of the sympatric zone to the higher end of the sympatric zone.
OWE has been observed to breed in India at $3000 \mathrm{~m}$ altitude in the Himalayas (Ripley, 1982), where in the summer, the mean annual temperatures range from 15 to 18 ${ }^{\circ} \mathrm{C}$. However, in Sri Lanka, the highest point OWE was found was $2484 \mathrm{~m}$ a.s.l., and only the SLWE could be observed beyond this elevation. The mean annual temperature at these elevations, where the SLWE breeds, is below $15^{\circ} \mathrm{C}$. On average, the sympatric zone of the two species has a mean annual temperature in the range of 15 to $17{ }^{\circ} \mathrm{C}$, whereas the allopatric zone of OWE has a mean annual temperature of above $22{ }^{\circ} \mathrm{C}$. Therefore, it seems that temperature does not limit the distribution of the OWE.

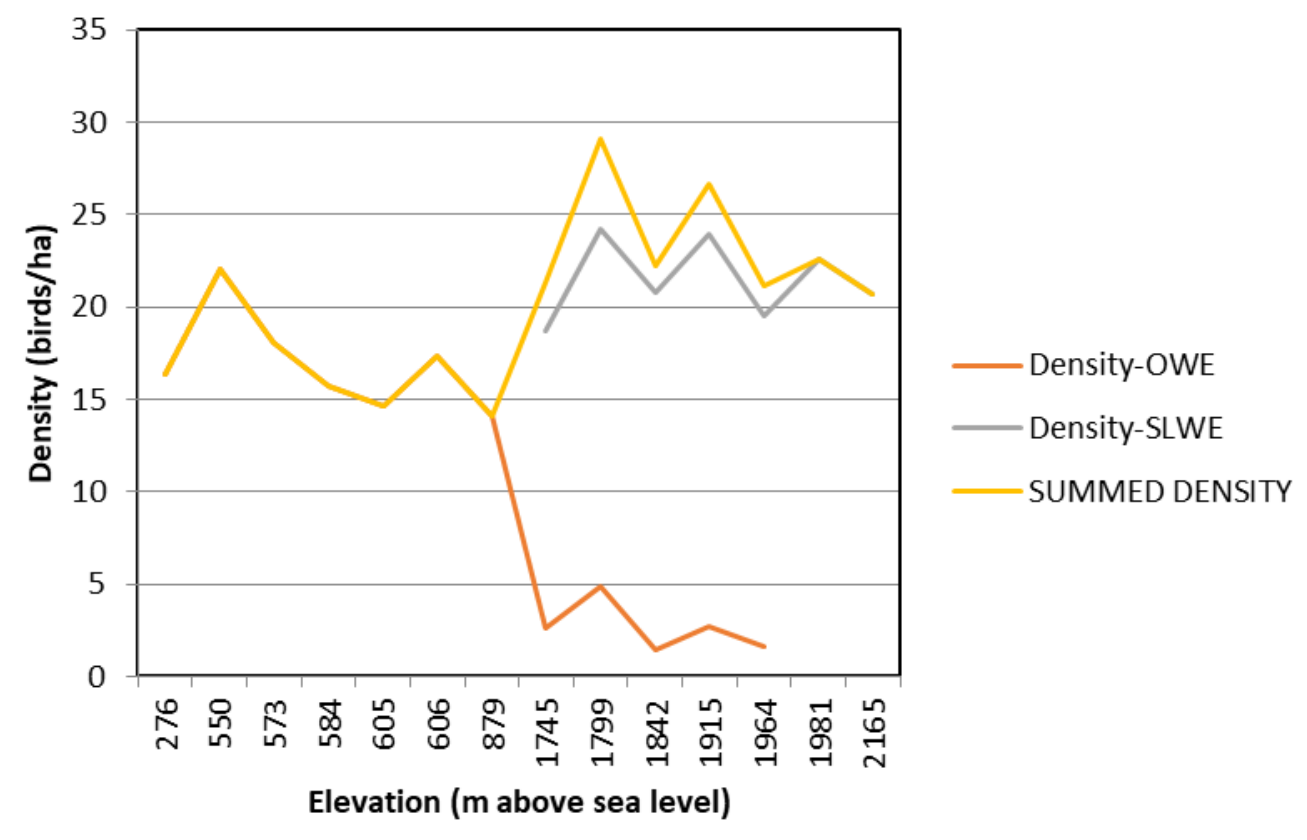

Figure 2: Density of the Oriental White-Eye (OWE) and Sri Lanka White-Eye (SLWE) on an altitudinal gradient.

\section{CONCLUSIONS}

According to the results obtained by the present study, the reasons for replacement of the OWE with the SLWE may partly be related to changes in vegetation structure along with competition from its congeneric species. The
SLWE was found in its maximum density in the sympatric zone. The coexistence of the two congeneric species has resulted in divergence of foraging heights and morphological characters in the sympatric zone. 


\section{REFERENCES}

Ali, S. and Ripley, S. D. (2001). Handbook of the Birds of India and Pakistan together with those of Bangladesh, Nepal, Bhutan, and Sri Lanka. Second Edition. Oxford University Press, Delhi, India.

Andrén, H. (1992). Corvid density and nest predation in relation to forest fragmentation: a landscape perspective. Ecology, 73, 794804.

Blasco, F., Bellan, M. F. and Aizpuru, M. (1996). A vegetation map of tropical continental Asia at scale 1:5 million. Journal of Vegetation Science, 7, 623-634.

Buckland, S. T., Anderson, D. R., Burnham, K. P. and Laake, J. L. (1993). Distance Sampling: Estimating Abundance of Biological Populations. Chapman and Hall, London, U.K.

Buckland, S. T., Anderson, D. R., Burnham, K. P., Laake, J. L., Borchers, D. L. and Thomas, L. (2001). Introduction to Distance Sampling: Estimating Abundance of Biological Populations. Oxford University Press, Oxford, U.K.

Cody, M. L. (1981). Habitat selection in birds: The roles of vegetation structure, competitors, and productivity. BioScience, 31, 107-113.

Cody, M. L. (1983). Bird diversity and density in South African forests. Oecologia, 59, 201215.

Diamond, J. M. (1973). Distributional ecology of New Guinea birds. Science, 179, 759-769.

Fischer, R. A., Valente, J. J., Guilfoyle, M. P., Kaller, M. D., Jackson, S. S. and Ratti, J. T. (2012). Bird community response to vegetation cover and composition in riparian habitats dominated by Russian olive (Elaeagnus angustifolia). Northwest Science, $86,39-52$.

Fondell, T. F. and Ball, I. J. (2004). Density and success of bird nests relative to grazing on western Montana grasslands. Biological Conservation, 117, 203-213.
Grant, P. R. (1972). Convergent and divergent character displacement. Biological Journal of the Linnean Society, 4, 39-68.

Haffer, J. (1969). Speciation in Amazonian forest birds. Science, 165, 131-137.

Haffer, J. (1974). Avian speciation in tropical South America: with a systematic survey of the Toucans (Ramphastidae) and Jacamars (Galbulidae). Nuttall Ornithological Club, Cambridge, Massachusetts, U.S.A.

Henry, G. M. (1971). A Guide to the Birds of Ceylon. Second Edition. Oxford University Press, London, U.K.

Henry, G. M. (1998). A Guide to the Birds of Sri Lanka. Third edition. K.V.G. de Silva and Sons, Kandy, Sri Lanka.

Hooper, R. G., Crawford, H. S. and Harlow, R. F. (1973). Bird density and diversity as related to vegetation in forest recreational areas. Journal of Forestry, 71, 766-769.

James, F. C. and Wamer, N. O. (1982). Relationships between temperate forest bird communities and vegetation structure. Ecology, 63, 159-171.

Kinley, T. A. and Newhouse, N. J. (1997). Relationship of riparian reserve zone width to bird density and diversity in southeastern British Columbia. Northwest Science, 71, 7586.

Kutt, A. S. (1996). Bird populations density in thinned, unthinned and old lowland regrowth forest, East Gippsland, Victoria. Emu, 96, 280284.

Legge, W. V. (1880). A History of the Birds of Ceylon-2 Vols. Published by the Author, London, U.K.

Lisboa, C. M. C. A. and Freire, E. M. X. (2012). Population density, habitat selection and conservation of Coleodactylus natalensis (Squamata: Phaerodactylidae) in an urban fragment of atlantic forest in northeastern Brazil. South American Journal of Herpetology, 7, 181-190. 
MacArthur, R. H., Diamond, J. M. and Karr, J. R. (1972). Density compensation in island faunas. Ecology, 53, 330-342.

MacNally, R. C. (1990). An analysis of density responses of forest and woodland birds to composite physiognomic variables. Australian Journal of Ecology, 15, 267-275.

Mallet-Rodrigues, F., Parrini, R., Pimentel, L. M. S. and Bessa, R. (2010). Altitudinal distribution of birds in a mountainous region in southeastern Brazil. Zoologia, 27, 503-522.

Mills, G. S., Dunning Jr, J. B. and Bates, J. M. (1991). The relationship between breeding bird density and vegetation volume. Wilson Bulletin, 103: 468-479.

Minitab, Inc. (2010). Minitab 15. Minitab Inc., State College, Pennsylvania, U.S.A.

Moreira, F. (1999). Relationships between vegetation structure and breeding bird densities in fallow cereal steppes in Castro Verde, Portugal. Bird Study, 46, 309-318.

Mulwa, R. K., Bennun, L. A., Ogol, C. K. P. O. and Lens, L. (2007). Population status and distribution of Taita White-eye Zosterops silvanus in the fragmented forests of Taita Hills and Mount Kasigau, Kenya. Biodiversity Conservation, 17, 141-150.

Perera, N. P. (1975). A physiognomic vegetation map of Sri Lanka (Ceylon). Journal of Biogeography 2: 185-203.

Pianka, E. R. (1981). Competition and niche theory. Pp. 167-196. In: May, R. M. (Ed.). Theoretical Ecology. Blackwell Scientific Publications, Oxford, U.K.

Ripley, S. D. (1982). A Synopsis of the Birds of India and Pakistan: together with those of Nepal, Bhutan, Bangladesh, and Sri Lanka. Second Edition. Bombay Natural History Society, Bombay, India.

Sutherland, W. J., Newton, I. and Green, R. E. (2004). Bird Ecology and Conservation: A Handbook of Techniques. Oxford University Press, Oxford, U.K.
Swift, B. L., Larson, J. S. and DeGraaf, R. M. (1984). Relationship of breeding bird density and diversity to habitat variables in forested wetlands. Wilson Bulletin, 96: 48-59.

Terborgh, J. (1971). Distribution on environmental gradeints: Theory and a preliminary interpretation of distributional patterns in the avifauna of the Cordellera Vilcabama, Peru. Ecology, 52, 23-40.

Terborgh, J. (1977). Bird species diversity on an Andean elevational gradient. Ecology, 58, 1007-1019.

Thomas, L., Buckland, S. T., Burham, K. P., Anderson, D. R., Laake, J. L., Borchers, D. L. and Strindberg, S. (2002). Distance Sampling. pp. 544-552. In: Encyclopedia of Environmetrics. El-Shaarawi, A. H. and W. W. Iegorsch, (Eds.). John Wiley and Sons, Ltd., Chichester, U.K.

Thomas, L., Buckland, S. T., Rexstad, E. A., Laake, J. L., Strindberg, S., Hedley, S. L., Bishop, J. R., Marques, T. A. and Burnham, K. P. (2010a). Distance software: design and analysis of distance sampling surveys for estimating population size. Journal of Applied Ecology,47, 5-14.

Thomas, L., Laake, J. L., Strindberg, S., Marques, F. F. C., Buckland, S. T., Borchers, D. L., Anderson, D. R., Burnham, K. P., Hedley, S. L., Pollard, J. H., Bishop, J. R. B. and Marques, T. A. (2010b). Distance 6.2. Research Unit for Wildlife Population Assessment, University of St. Andrews, UK.

Wait, W. E. (1922). The Passerine Birds of Ceylon. Spolia Zeylanica, 22-198.

Wait, W. E. (1925). Manual of the Birds of Ceylon. Dulau and Co., Ltd., London, U.K.

Wiens, J. A. (1989). The Ecology of Bird Communities. Vol. I: Foundations and Patterns. Cambridge University Press, Cambridge, U.K.

Wijesundara, C. S. and Freed, L. A. (2018). Divergence of morphological characters in two white-eye species (Passeriformes: 
Zosteropidae) in sympatry. Ecosphere, 9, e02317.

Winter, M., Johnson, D. H. and Shaffer, J. A. (2005). Variability in vegetation effects on density and nesting success of grassland birds. Journal of Wildlife Management, 69, 185-197.

Ali, S. and Ripley, S. D. (2001). Handbook of the Birds of India and Pakistan together with those of Bangladesh, Nepal, Bhutan, and Sri Lanka. Second Edition. Oxford University Press, Delhi, India.

Andrén, H. (1992). Corvid density and nest predation in relation to forest fragmentation: a landscape perspective. Ecology, 73, 794804.

Blasco, F., Bellan, M. F. and Aizpuru, M. (1996). A vegetation map of tropical continental Asia at scale 1:5 million. Journal of Vegetation Science, 7, 623-634.

Buckland, S. T., Anderson, D. R., Burnham, K. P. and Laake, J. L. (1993). Distance Sampling: Estimating Abundance of Biological Populations. Chapman and Hall, London, U.K.

Buckland, S. T., Anderson, D. R., Burnham, K. P., Laake, J. L., Borchers, D. L. and Thomas, L. (2001). Introduction to Distance Sampling: Estimating Abundance of Biological Populations. Oxford University Press, Oxford, U.K.

Cody, M. L. (1981). Habitat selection in birds: The roles of vegetation structure, competitors, and productivity. BioScience, 31, 107-113.

Cody, M. L. (1983). Bird diversity and density in South African forests. Oecologia, 59, 201215.

Diamond, J. M. (1973). Distributional ecology of New Guinea birds. Science, 179, 759-769.

Fischer, R. A., Valente, J. J., Guilfoyle, M. P., Kaller, M. D., Jackson, S. S. and Ratti, J. T. (2012). Bird community response to vegetation cover and composition in riparian habitats dominated by Russian olive (Elaeagnus angustifolia). Northwest Science, 86, 39-52.

Fondell, T. F. and Ball, I. J. (2004). Density and success of bird nests relative to grazing on western Montana grasslands. Biological Conservation, 117, 203-213.

Grant, P. R. (1972). Convergent and divergent character displacement. Biological Journal of the Linnean Society, 4, 39-68.

Haffer, J. (1969). Speciation in Amazonian forest birds. Science, 165, 131-137.

Haffer, J. (1974). Avian speciation in tropical South America: with a systematic survey of the Toucans (Ramphastidae) and Jacamars (Galbulidae). Nuttall Ornithological Club, Cambridge, Massachusetts, U.S.A.

Henry, G. M. (1971). A Guide to the Birds of Ceylon. Second Edition. Oxford University Press, London, U.K.

Henry, G. M. (1998). A Guide to the Birds of Sri Lanka. Third edition. K.V.G. de Silva and Sons, Kandy, Sri Lanka.

Hooper, R. G., Crawford, H. S. and Harlow, R. F. (1973). Bird density and diversity as related to vegetation in forest recreational areas. Journal of Forestry, 71, 766-769.

James, F. C. and Wamer, N. O. (1982). Relationships between temperate forest bird communities and vegetation structure. Ecology, 63, 159-171.

Kinley, T. A. and Newhouse, N. J. (1997). Relationship of riparian reserve zone width to bird density and diversity in southeastern British Columbia. Northwest Science, 71, 7586.

Kutt, A. S. (1996). Bird populations density in thinned, unthinned and old lowland regrowth forest, East Gippsland, Victoria. Emu, 96, 280284. 
Legge, W. V. (1880). A History of the Birds of Ceylon-2 Vols. Published by the Author, London, U.K.

Lisboa, C. M. C. A. and Freire, E. M. X. (2012). Population density, habitat selection and conservation of Coleodactylus natalensis (Squamata: Phaerodactylidae) in an urban fragment of atlantic forest in northeastern Brazil. South American Journal of Herpetology, 7, 181-190.

MacArthur, R. H., Diamond, J. M. and Karr, J. R. (1972). Density compensation in island faunas. Ecology, 53, 330-342.

MacNally, R. C. (1990). An analysis of density responses of forest and woodland birds to composite physiognomic variables. Australian Journal of Ecology, 15, 267-275.

Mallet-Rodrigues, F., Parrini, R., Pimentel, L. M. S. and Bessa, R. (2010). Altitudinal distribution of birds in a mountainous region in southeastern Brazil. Zoologia, 27, 503-522.

Mills, G. S., Dunning Jr, J. B. and Bates, J. M. (1991). The relationship between breeding bird density and vegetation volume. Wilson Bulletin, 103: 468-479.

Minitab, Inc. (2010). Minitab 15. Minitab Inc., State College, Pennsylvania, U.S.A.

Moreira, F. (1999). Relationships between vegetation structure and breeding bird densities in fallow cereal steppes in Castro Verde, Portugal. Bird Study, 46, 309-318.

Mulwa, R. K., Bennun, L. A., Ogol, C. K. P. O. and Lens, L. (2007). Population status and distribution of Taita White-eye Zosterops silvanus in the fragmented forests of Taita Hills and Mount Kasigau, Kenya. Biodiversity Conservation, 17, 141-150.

Perera, N. P. (1975). A physiognomic vegetation map of Sri Lanka (Ceylon). Journal of Biogeography 2: 185-203.

Pianka, E. R. (1981). Competition and niche theory. Pp. 167-196. In: May, R. M. (Ed.).
Theoretical Ecology. Blackwell Scientific Publications, Oxford, U.K.

Ripley, S. D. (1982). A Synopsis of the Birds of India and Pakistan: together with those of Nepal, Bhutan, Bangladesh, and Sri Lanka. Second Edition. Bombay Natural History Society, Bombay, India.

Sutherland, W. J., Newton, I. and Green, R. E. (2004). Bird Ecology and Conservation: A Handbook of Techniques. Oxford University Press, Oxford, U.K.

Swift, B. L., Larson, J. S. and DeGraaf, R. M. (1984). Relationship of breeding bird density and diversity to habitat variables in forested wetlands. Wilson Bulletin, 96: 48-59.

Terborgh, J. (1971). Distribution on environmental gradeints: Theory and a preliminary interpretation of distributional patterns in the avifauna of the Cordellera Vilcabama, Peru. Ecology, 52, 23-40.

Terborgh, J. (1977). Bird species diversity on an Andean elevational gradient. Ecology, 58, 1007-1019.

Thomas, L., Buckland, S. T., Burham, K. P., Anderson, D. R., Laake, J. L., Borchers, D. L. and Strindberg, S. (2002). Distance Sampling. pp. 544-552. In: Encyclopedia of Environmetrics. El-Shaarawi, A. H. and W. W. Iegorsch, (Eds.). John Wiley and Sons, Ltd., Chichester, U.K.

Thomas, L., Buckland, S. T., Rexstad, E. A., Laake, J. L., Strindberg, S., Hedley, S. L., Bishop, J. R., Marques, T. A. and Burnham, K. P. (2010a). Distance software: design and analysis of distance sampling surveys for estimating population size. Journal of Applied Ecology,47, 5-14.

Thomas, L., Laake, J. L., Strindberg, S., Marques, F. F. C., Buckland, S. T., Borchers, D. L., Anderson, D. R., Burnham, K. P., Hedley, S. L., Pollard, J. H., Bishop, J. R. B. and Marques, T. A. (2010b). Distance 6.2. Research Unit for Wildlife Population Assessment, University of St. Andrews, UK. 
Wait, W. E. (1922). The Passerine Birds of Ceylon. Spolia Zeylanica, 22-198.

Wait, W. E. (1925). Manual of the Birds of Ceylon. Dulau and Co., Ltd., London, U.K.

Wiens, J. A. (1989). The Ecology of Bird Communities. Vol. I: Foundations and Patterns. Cambridge University Press, Cambridge, U.K.

Wijesundara, C. S. and Freed, L. A. (2018). Divergence of morphological characters in two white-eye species (Passeriformes: Zosteropidae) in sympatry. Ecosphere, 9, e02317.

Winter, M., Johnson, D. H. and Shaffer, J. A. (2005). Variability in vegetation effects on density and nesting success of grassland birds. Journal of Wildlife Management, 69, 185-197.

Wright, S. J. (1980). Density compensation in island avifaunas. Oecologia, 45, 385-389 